\title{
Healthcare workers' knowledge and attitude towards prompt referral of women with postpartum haemorrhage in Nigeria: a community- based study
}

\section{Adekemi Eunice Olowokere*, Aanuoluwapo Omobolanle Olajubu, Ifeoluwa Eunice Ayeni, Olayinka Olaitan Aremu}

Department of Nursing Science, Obafemi Awolowo University, Ile-Ife, Osun State, Nigeria

Received: 11 November 2019

Accepted: 07 December 2019

\section{*Correspondence:}

Dr. Adekemi Eunice Olowokere,

E-mail: ayaolowo@yahoo.com

Copyright: () the author(s), publisher and licensee Medip Academy. This is an open-access article distributed under the terms of the Creative Commons Attribution Non-Commercial License, which permits unrestricted non-commercial use, distribution, and reproduction in any medium, provided the original work is properly cited.

\begin{abstract}
Background: Postpartum Haemorrhage (PPH) is a major contributor to maternal mortality in developing countries most especially in the rural areas where Emergency Obstetric Care (EmOC) are not available. Delay in referring women from rural health facilities to settings where EmOC services are available have been reported. This study assessed community-based healthcare workers' (CHWs) knowledge and attitude towards the prevention, early recognition and prompt referral of women with Post-Partum Haemorrhage (PPH) for Emergency Obstetric Care (EmOC).

Methods: Descriptive cross-sectional design was used. Structured questionnaire was used to collect data from 200 $\mathrm{CHWs}$ recruited from community-based healthcare. Data analysis was done in SPSS version 20 at significance level of 0.05 .

Results: Findings show that $86.5 \%(n=173)$ of the respondents had good knowledge while $12 \%(n=24)$ and $1.5 \%$ $(\mathrm{n}=3)$ had moderate and poor knowledge respectively. Negative attitude towards prompt referral of women affected with PPH was found among $51 \%(n=102)$ of the respondents. Unavailability of blood drapes to estimate blood loss $[\chi 2(1, \mathrm{n}=200)=4.51, \mathrm{p}=0.03]$, lack of ambulance $[\chi 2(1, \mathrm{n}=200)=4.46, \mathrm{p}=0.03]$, and poor state of the roads $\left[\chi^{2}(1\right.$, $\mathrm{n}=200)=4.44, \mathrm{p}=0.03]$ were factors linked to poor attitude of CHWs towards prompt referral of affected women.

Conclusions: The study concluded that there is a need for intervention that can help improve community healthcare workers' attitude towards prompt referral of women affected with postpartum haemorrhage. There is also a need for general overhaul of community-based facilities to effectively support prompt referral.
\end{abstract}

Keywords: Attitude towards referral, Community-based healthcare workers, Early recognition of postpartum haemorrhage, Emergency obstetric care, Knowledge of postpartum haemorrhage, Maternal mortality

\section{INTRODUCTION}

Mortality due to complications of pregnancy and child birth in Nigeria has been documented to be relatively high. ${ }^{1}$ Nigeria has maternal mortality ratio of 814 maternal deaths/100,000 of live births and was the largest contributor to maternal deaths in the world in the year
2015. ${ }^{1}$ Nigeria only achieved $6 \%$ decline in maternal mortality ratio over a period of five years from 867 maternal deaths $/ 100,000$ in 2010 to 814 maternal deaths/100,000 in 2015. Though there is progress towards reduction in mortality rate, this has been very low. Postpartum haemorrhage (PPH) has been identified as a significant contributor to this severe maternal mortality 
among women. ${ }^{2-4}$ World Health Organization statistics suggest that $60 \%$ of maternal deaths in developing countries are due to $\mathrm{PPH} .^{5}$

Post-partum haemorrhage is defined as blood loss of more than $500 \mathrm{ml}$ following vaginal delivery or more than $1000 \mathrm{ml}$ following cesarean delivery. ${ }^{6}$ Postpartum haemorrhage can be primary or secondary. It is primary when it occurs within 24 hours of birth and secondary when it occurs after 24 hours to 42 days of puerperium. It has been documented that most deaths resulting from PPH occur during the first 24 hours after birth. ${ }^{7}$ Appropriate management of women during this period and prompt referral to where emergency obstetric care (EmOC) can be accessed will prevent majority of these deaths most especially for women at the grassroots level

In Nigeria, there are three levels of healthcare service delivery; the primary, secondary and tertiary levels. The primary healthcare service delivery facilities are facilities located within close range to community members and most times they are usually the first point of contact for women. However, these facilities often lack resources for EmOC most especially manpower and equipment to administer such care. These facilities are being controlled by the local government and they include primary health care (PHC) facilities. Both the secondary and tertiary facilities are controlled by state and federal governments and are capable of providing EmOC services. Among these three levels of care, there is often referral from one level to the other. If primary PPH occurs in a woman delivering in community-based facilities where there are no facilities for EmOC, the professionals on site would institute first aid measures while promptly arranging transport to facilities where EmOC services are available. In Nigeria, the referral system can be said to be, at best, non-operational and there is just no continuity of care, and neither is there any proper link between the facilities at the grassroots level and those at the secondary and the tertiary levels. ${ }^{8}$ This contributes specially to increased maternal and child morbidities and mortalities. Hence, this study assessed the knowledge of CHWs on prevention, early recognition and referral of PPH cases and their attitude towards prompt referral of women with postpartum hemorrhage. For the purpose of this study, CHWs are healthcare providers who attend to women during pregnancy, childbirth and postpartum period and work at the primary health care facilities, and community-based maternity hospitals that have no facilities for EmOC.

\section{METHODS}

A descriptive cross-sectional design was employed in this study. The study took place in community-based healthcare facilities located in different rural communities of Ife North and Ife east local government areas (LGAs) of Osun state in Southwestern Nigeria. Ife east LGA has 13 community-based hospitals/maternities and 17 primary health care facilities (PHCF) while Ife North has
3 community-based hospital/maternity and 25 PHCF. The two LGAs have no secondary or tertiary healthcare facilities that offer EmOC services.

Multistage sampling technique was used to select CHWs from Ife East and Ife North LGAs. Firstly, a random sampling technique was used to select one Senatorial District (Osun East) out of the 3 districts in Osun state. Secondly, two LGAs (Ife East and Ife North) were randomly selected from the ten LGAs in Osun East Senatorial district. The sample size was determined by using a standard sample calculation formula $(\mathrm{n})=$ $\mathrm{N} /\left[1+\mathrm{N}(\mathrm{e})^{2}\right]$, where $\mathrm{n}=$ sample size, $\mathrm{N}=$ total number of accessible CHWs (385) in the two LGAs, e=constant (0.05). ${ }^{9}$ Using this formula, a sample size of 196 was obtained and this was increased to 200 being a survey. Fifty percent of the facilities were randomly selected from each LGA and number of respondents recruited from each facility was done by proportionate sampling. All nurses in the two settings (LGAs) were purposively recruited into the study because they were few compare with other $\mathrm{CHW}$. Other $\mathrm{CHW}$ s that participated in the study were selected by simple random sampling technique through balloting. Only $\mathrm{CHW}$ s that work at the community-based facilities were included in the study while those who work at the secondary and tertiary healthcare facilities were excluded from the study.

A structured questionnaire was used to collect the data. The questionnaire was developed from previous studies on knowledge of post-partum hemorrhage..$^{8,10}$ The validity and reliability of the instrument were established in a pre-test and pilot study prior to data collection. The reliability coefficient using test-retest method was 0.89 . Questionnaire was administered directly to the CHWs upon taking their consent to participate in the study.

Analysis was done in IBM SPSS Statistics for Windows software version 20 (IBM Corporation, Armonk, NY, USA). A total of nineteen questions were used to assess respondents' knowledge of prevention, early recognition and referral of PPH cases. Each question from the questionnaire had weight attached to them to create a composite score of the knowledge. Maximum score obtainable was 19 points and points were awarded on a discrete (whole number) rather than a continuous scale, based on the number of positive responses. Scores were converted to percentage and categorized as good for a score of $70 \%$ or more, moderate for those who scored between $50 \%$ and $69 \%$ and poor for a score below $50 \%$. Respondents' attitude was measured by eleven attitudinal statements on a four-point Likert Scale ranging from strongly disagree (1) to strongly agree (4) such that higher scores reflect better attitude. The scores were dichotomized into positive and negative attitude using the median score. Respondents with median score and above were categorized as having positive attitude towards referral while those that score below the median score were categorized as having negative attitude towards referral. For the factors influencing referral of women 
with PPH, descriptive statistics was used to present the findings using bar graph. Chi-square $(\chi 2)$ test and Kruskal Wallis independent sample test were used to test association and differences between variables at significance level of $\mathrm{p}<0.05$.

Ethical approval for the study was obtained from the health research ethics committee (HREC Number: IPH/OAU/12/650) of the Institute of Public Health, Obafemi Awolowo University, Ile-Ife. Verbal consent of individual participants was obtained prior to the administration of questionnaire. The survey was anonymous and participation was voluntary.

\section{RESULTS}

\section{Socio-demographic characteristics of respondents}

Table 1 presents the socio-demographic characteristics of the respondents. The mean age of the respondents was 36.8 \pm 8.7 . Majority of the CHWs at the study settings were community health extension workers (CHEWs). The mean year of experience of the CHWs was $11.16 \pm 7.4$.

\section{Knowledge of prevention, early recognition and referral of postpartum haemorrhage cases}

As shown in Table 2, Majority of the respondents were knowledgeable on most of the knowledge items.

On the overall, $86.5 \%(n=173)$ of the respondents had good knowledge, $12 \%(\mathrm{n}=24)$ had moderate knowledge while $1.5 \%(\mathrm{n}=3)$ had poor knowledge of prevention, early recognition and prompt referral of women with $\mathrm{PPH}$.

\section{Attitude of health workers towards prompt referral of women with postpartum haemorrhage}

Table 3 summarises the attitude of CHWs towards the prompt referral of women with PPH. On the whole, about half $(51 \%)$ of the CHWs have a negative attitude towards prompt referral of women with $\mathrm{PPH}$.

There was a significant difference among the different professional groups of $\mathrm{CHWs}$ with regards to their knowledge $[\chi 2(3, \mathrm{n}=200)=4.48, \mathrm{p}=0.000]$ and attitudes $[\chi 2(3, \mathrm{n}=200)=32.11, \mathrm{p}=0.000]$ towards referral of women with PPH as shown in (Table 4).

\section{Factors influencing referral of women with postpartum haemorrhage}

Factors identified by CHWs to influence referral of women with PPH are as presented in Figure 1. Lack of blood drapes to evaluate blood loss, lack of ambulance and state of the road were statistically associated with attitude of CHWs towards referral of women with PPH (Table 5).

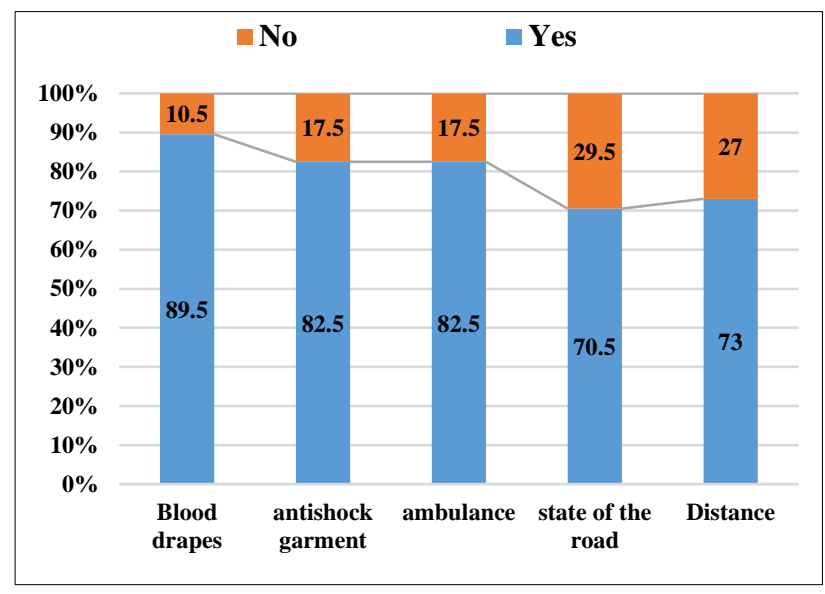

Figure 1: Factors that influence referral of patients with PPH.

Table 1: Sociodemographic profile of respondents.

\begin{tabular}{|lcc|}
\hline Characteristics of population & $\mathbf{n}=\mathbf{2 0 0}$ & $\%$ \\
\hline Age (years) & 38 & 19.0 \\
\hline $20-29$ & 80 & 40.0 \\
\hline $30-39$ & 62 & 31.0 \\
\hline $40-49$ & 20 & 10.0 \\
\hline 50 and above & & \\
\hline Gender & 24 & 12.0 \\
\hline Male & 176 & 88.0 \\
\hline Female & & \\
\hline Marital status & 39 & 19.5 \\
\hline Single & 147 & 73.5 \\
\hline Married & 14 & 7.0 \\
\hline Divorced & 157 & 78.5 \\
\hline Religion & 40 & 20.0 \\
\hline Christianity & 3 & 1.5 \\
\hline Islam & 62 & 31.0 \\
\hline Traditional & 10 & 5.0 \\
\hline Cadre of community health workers (CHWs) & \\
\hline Nurses & 70 & 29.0 \\
\hline Community health officer & 58 & \\
\hline $\begin{array}{l}\text { Community health extension } \\
\text { workers }\end{array}$ & & \\
\hline Health assistants & & \\
\hline
\end{tabular}

\section{DISCUSSION}

Post-partum haemorrhage, being one of the leading causes of maternal mortality and morbidity, needs to be controlled to reduce mortality associated with it. Studies have suggested that several deaths associated with PPH could be prevented when recognized early and given proper management. ${ }^{11,12}$ This could only be possible for women in the rural areas if referral is initiated early and properly executed. 
Table 2: Knowledge of early recognition, prevention, and referral of PPH cases.

\begin{tabular}{|c|c|c|c|}
\hline Knowledge items & Correct response & Yes, $\mathbf{n}(\%)$ & No, $n(\%)$ \\
\hline \multicolumn{4}{|l|}{ Postpartum haemorrhage (PPH) is } \\
\hline Loss of more than $500 \mathrm{mls}$ of blood after vaginal delivery & Yes & $188(94.0 \%)$ & $12(6.0 \%)$ \\
\hline \multicolumn{4}{|l|}{ Symptoms of PPH may include } \\
\hline Bleeding per vagina after delivery & Yes & $164(82.0 \%)$ & $36(18.0 \%)$ \\
\hline Fast and weak pulse with fast respiratory rate & Yes & $165(82.5 \%)$ & $35(17.5 \%)$ \\
\hline Pallor, pale eyelid, palms and mucus membrane & Yes & $164(82.0 \%)$ & $36(18.0 \%)$ \\
\hline Confusion and loss of consciousness & Yes & $161(80.5 \%)$ & $39(18.5 \%)$ \\
\hline Decrease in blood pressure & Yes & $167(83.5 \%)$ & $33(16.5 \%)$ \\
\hline \multicolumn{4}{|l|}{ Identification of PPH } \\
\hline Taking comprehensive past obstetric history & Yes & $176(88.0 \%)$ & $24(12.0 \%)$ \\
\hline Use of blood collection drapes to assess amount of blood loss & Yes & $152(76.0 \%)$ & $48(24.0 \%)$ \\
\hline Monitoring of vital signs & Yes & $185(92.5 \%)$ & $5(7.5 \%)$ \\
\hline \multicolumn{4}{|l|}{ Prevention of PPH } \\
\hline $\begin{array}{l}\text { Referral of high-risk pregnant woman to secondary/tertiary health care } \\
\text { level }\end{array}$ & Yes & $176(88.0 \%)$ & $24(12.0 \%)$ \\
\hline Early recognition of signs of PPH & Yes & $152(76.0 \%)$ & $48(24.0 \%)$ \\
\hline Active management of third stage of labour & Yes & $185(92.5 \%)$ & $15(7.5 \%)$ \\
\hline Avoid routine episiotomy & Yes & $183(91.5 \%)$ & $17(8.5 \%)$ \\
\hline \multicolumn{4}{|l|}{ Referral of PPH cases } \\
\hline $\begin{array}{l}\text { A woman who lost about } 300 \mathrm{ml} \text { of blood through vaginal delivery at the } \\
\text { community facilities should be prepared for referral to the next level of } \\
\text { care. }\end{array}$ & Yes & $158(79.0 \%)$ & $42(21.0 \%)$ \\
\hline $\begin{array}{l}\text { PPH could be easily managed at the community facility with drugs and } \\
\text { fluid only }\end{array}$ & No & $29(14.5 \%)$ & $171(85.5 \%)$ \\
\hline $\begin{array}{l}\text { A woman who lost } 500 \mathrm{mls} \text { of blood through vaginal delivery would need } \\
\text { referral for emergency obstetric care immediately }\end{array}$ & Yes & $21(10.5 \%)$ & $179(89.5 \%)$ \\
\hline $\begin{array}{l}\text { A woman should only be transferred to the next level of care if she has lost } \\
1000 \mathrm{mls} \text { of blood after vaginal delivery }\end{array}$ & No & $150(75.0 \%)$ & $50(25.0 \%)$ \\
\hline $\begin{array}{l}\text { Anti-shock garment can be used to prevent /manage shock in women with } \\
\text { PPH before referral }\end{array}$ & Yes & $124(62.0 \%)$ & $76(38.0 \%)$ \\
\hline $\begin{array}{l}\text { PPH can be arrested without referral if the woman is given a local mixture } \\
\text { of Ugwu leaf and soft drink (maltina) }\end{array}$ & No & $98(49.0 \%)$ & $102(51.0 \%)$ \\
\hline
\end{tabular}

Table 3: Respondent's attitude towards prompt referral of women with PPH.

\begin{tabular}{|c|c|c|c|c|}
\hline Attitudinal items & $\begin{array}{l}\text { SA } \\
\text { n }(\%)\end{array}$ & $\begin{array}{l}\text { A } \\
\text { n }(\%)\end{array}$ & $\begin{array}{l}\text { D } \\
\text { n }(\%)\end{array}$ & $\begin{array}{l}\text { SD } \\
\text { n }(\%)\end{array}$ \\
\hline $\begin{array}{l}\text { Women should not be referred to secondary or tertiary health facility for excessive } \\
\text { bleeding of more than } 500 \mathrm{ml}\end{array}$ & $\begin{array}{l}74 \\
37.0 \%\end{array}$ & $\begin{array}{l}17 \\
8.5 \%\end{array}$ & $\begin{array}{l}37 \\
18.5 \%\end{array}$ & $\begin{array}{l}72 \\
36.0 \%\end{array}$ \\
\hline $\begin{array}{l}\text { Women need not be referred to secondary or tertiary health facility for bleeding of less } \\
\text { than } 300 \mathrm{ml}\end{array}$ & $\begin{array}{l}86 \\
43.0 \%\end{array}$ & $\begin{array}{l}56 \\
28.0 \%\end{array}$ & $\begin{array}{l}39 \\
19.5 \%\end{array}$ & $\begin{array}{l}19 \\
9.5 \%\end{array}$ \\
\hline $\begin{array}{l}\text { Fast and weak pulse with fast respiratory rate are signs of loss of } 20 \% \text { of blood and should } \\
\text { not necessitate referral }\end{array}$ & $\begin{array}{l}84 \\
42.0 \%\end{array}$ & 31 & $\begin{array}{l}49 \\
24.5 \%\end{array}$ & $\begin{array}{l}36 \\
18.0 \%\end{array}$ \\
\hline $\begin{array}{l}\text { Marked pallor, pale eyelid, palms and mucus membrane are signs of postpartum } \\
\text { haemorrhage and need no referral because it can be managed at community level }\end{array}$ & $\begin{array}{l}65 \\
32.5 \% \\
\end{array}$ & $\begin{array}{l}47 \\
23.5 \%\end{array}$ & $\begin{array}{l}39 \\
19.5 \%\end{array}$ & $\begin{array}{l}49 \\
24.5 \%\end{array}$ \\
\hline $\begin{array}{l}\text { Women with decrease in blood pressure that is unstable even in supine position should not } \\
\text { be referred. }\end{array}$ & 67 & $\begin{array}{l}44 \\
22.0 \%\end{array}$ & $\begin{array}{l}50 \\
25.0 \%\end{array}$ & $\begin{array}{l}39 \\
19.5 \%\end{array}$ \\
\hline $\begin{array}{l}\text { Tachycardia, oliguria, confusion and loss of consciousness are signs of loss of }>40 \% \text { of } \\
\text { blood and should not necessitate referral but should be managed at community level }\end{array}$ & $\begin{array}{l}66 \\
33.0 \%\end{array}$ & $\begin{array}{l}32 \\
16.0 \%\end{array}$ & $\begin{array}{l}46 \\
23.0 \%\end{array}$ & $\begin{array}{l}56 \\
28.0 \%\end{array}$ \\
\hline $\begin{array}{l}\text { Prolong labour }>18 \text { hours should not be referred for EmOC but should be managed at } \\
\text { community level }\end{array}$ & $\begin{array}{l}53 \\
26.5 \%\end{array}$ & $\begin{array}{l}22 \\
11.0 \%\end{array}$ & $\begin{array}{l}49 \\
24.5 \%\end{array}$ & $\begin{array}{l}76 \\
38.0 \%\end{array}$ \\
\hline Bleeding in ante and intra partum period need no referral & $\begin{array}{l}45 \\
22.5 \%\end{array}$ & $\begin{array}{l}39 \\
19.5 \%\end{array}$ & $\begin{array}{l}48 \\
24.0 \%\end{array}$ & $\begin{array}{l}68 \\
34.0 \% \\
\end{array}$ \\
\hline Women with uterine atony needs no referral & $\begin{array}{l}43 \\
21.5 \%\end{array}$ & $\begin{array}{l}51 \\
25.5 \%\end{array}$ & $\begin{array}{l}47 \\
23.5 \%\end{array}$ & $\begin{array}{l}59 \\
29.5 \%\end{array}$ \\
\hline Women with history of postpartum haemorrhage do not need referral & $\begin{array}{l}40 \\
20.0 \%\end{array}$ & $\begin{array}{l}26 \\
13.0 \%\end{array}$ & $\begin{array}{l}59 \\
29.5 \%\end{array}$ & $\begin{array}{l}75 \\
37.5 \%\end{array}$ \\
\hline $\begin{array}{l}\text { High risk pregnant women can be comfortably managed at community level and should } \\
\text { not be referred }\end{array}$ & $\begin{array}{l}46 \\
23.0 \%\end{array}$ & $\begin{array}{l}24 \\
12.0 \%\end{array}$ & $\begin{array}{l}46 \\
23.0 \%\end{array}$ & $\begin{array}{l}84 \\
42.0 \%\end{array}$ \\
\hline
\end{tabular}

SA: strongly agree, A: agree, D: disagree, SD: strongly disagree. 
Table 4: Independent sample results of difference in knowledge and attitude scores among professional groups.

\begin{tabular}{|c|c|c|c|c|c|}
\hline Group & $\mathbf{n}$ & Mean rank & df & $\chi^{2}$ & p-value \\
\hline \multicolumn{6}{|l|}{ Knowledge } \\
\hline Nurses/midwives & 62 & 106.06 & \multirow{5}{*}{3} & \multirow{5}{*}{4.48} & \multirow{5}{*}{0.000} \\
\hline $\mathrm{CHO}$ & 10 & 83.33 & & & \\
\hline CHEW & 70 & 98.33 & & & \\
\hline HA & 58 & 100.18 & & & \\
\hline Total & 200 & & & & \\
\hline \multicolumn{6}{|l|}{ Attitude } \\
\hline Nurses/midwives & 62 & 112.90 & \multirow{5}{*}{3} & \multirow{5}{*}{32.11} & \multirow{5}{*}{0.000} \\
\hline $\mathrm{CHO}$ & 10 & 70.00 & & & \\
\hline CHEW & 70 & 77.14 & & & \\
\hline HA & 58 & 120.69 & & & \\
\hline Total & 200 & & & & \\
\hline
\end{tabular}

Table 5: Chi-square test of association between factors and attitude on postpartum haemorrhage.

\begin{tabular}{|c|c|c|c|c|c|c|}
\hline \multirow{2}{*}{ Factors } & & \multicolumn{2}{|l|}{ Attitude } & \multirow{2}{*}{ Total } & \multirow{2}{*}{$\begin{array}{l}\chi^{2}, p-\text { value } \\
(\mathrm{df}=1)\end{array}$} & \multirow{2}{*}{ Phi (e) } \\
\hline & & Negative & Positive & & & \\
\hline \multirow{2}{*}{$\begin{array}{l}\text { Lack of blood drapes to evaluate } \\
\text { blood loss }\end{array}$} & Yes & $95(47.5 \%)$ & $84(42.5 \%)$ & $179(89.5)$ & \multirow{2}{*}{$\begin{array}{l}\chi^{2}=4.51 \\
p=0.03\end{array}$} & \multirow{2}{*}{0.15} \\
\hline & No & $6(3.0 \%)$ & $15(7.0 \%)$ & $21(10.5)$ & & \\
\hline \multirow{2}{*}{ Lack of anti-shock garment } & Yes & $83(41.5 \%)$ & $82(41.0 \%)$ & $165(82.5)$ & \multirow{2}{*}{$\begin{array}{l}\chi^{2}=0.01 \\
\mathrm{p}=0.90\end{array}$} & \multirow{2}{*}{0.01} \\
\hline & No & $18(9.0 \%)$ & $17(8.5 \%)$ & $35(17.5)$ & & \\
\hline \multirow{2}{*}{ Lack of ambulance } & Yes & $89(44.5 \%)$ & $76(38.0 \%)$ & $165(82.5)$ & \multirow{2}{*}{$\begin{array}{l}\chi^{2}=4.46 \\
p=0.03\end{array}$} & \multirow{2}{*}{0.14} \\
\hline & No & $12(6.0)$ & $23(11.5 \%)$ & $35(17.5)$ & & \\
\hline \multirow{2}{*}{ State of the road } & Yes & $78(39.0 \%)$ & $63(31.5 \%)$ & $141(70.5)$ & \multirow{2}{*}{$\begin{array}{l}\chi^{2}=4.44 \\
p=0.03\end{array}$} & \multirow{2}{*}{0.14} \\
\hline & No & $23(11.5)$ & $36(18.0)$ & $59(29.5)$ & & \\
\hline \multirow{2}{*}{$\begin{array}{l}\text { Distance of referral centre to health } \\
\text { facilities }\end{array}$} & Yes & $72(36.0 \%)$ & $74(37.0 \%)$ & $146(73.0)$ & \multirow{2}{*}{$\begin{array}{l}\chi^{2}=0.30 \\
p=0.58\end{array}$} & \multirow{2}{*}{-0.03} \\
\hline & No & $29(14.5 \%)$ & $25(12.5 \%)$ & $54(17.0)$ & & \\
\hline
\end{tabular}

Findings from this study show that most of the CHWs are community health extension workers (CHEWs), this is consistent with the minimum standards for primary health care in Nigeria. ${ }^{13}$ However, members of this professional group including the community health officers $(\mathrm{CHO})$ and health assistants (HA) were not trained as midwives. They use hands on experience to care for women during pregnancy, delivery and post-partum period. Previous study has reported that skilled professionals in midwifery such as nurses-midwives and doctors prefer to work in the urban settings due to lack of basic amenities and opportunities for career development. ${ }^{14}$ There is need for high skilled staff at this level to facilitate prompt identification and referral of women with PPH. Considering the importance of community-based facilities in meeting the healthcare needs of people in the rural areas, there is need for all these facilities to be equipped with adequate manpower most especially midwives if Nigeria would achieve sustainable development goals in relation to maternal mortality ratio (MMR) under goal 3.

Majority of the CHWs had good knowledge of PPH identification, prevention and referral with nurses having the highest mean score. This is similar to a higher level of knowledge about PPH among nurse-midwives in previous studies conducted in Khartoum State, Sudan and Baghdad city, in Iraq. ${ }^{15,16}$ This finding is not unexpected since nurse-midwives had a higher level of training than other CHWs in this study.

It was also observed that some CHWs are of the opinion that a mixture of Ugwu (Telfara occidentalis) and a soft drink (Maltina) often used as local home remedy for the management of anaemia could be given to women who have PPH instead of referring for EmOC. This may be a dangerous thing to do because a woman with PPH may be in need of emergency surgery, and if she has been given a local remedy, she may stand the risk of aspiration and further complications. In addition, many patients' relatives do not provide or know the importance of giving detailed information of what they have already given to the women at the point of health care for the fear of unknown in relation to lack of knowledge of what is expected of them.

There is still poor knowledge on the use of antishock garments and the amount of blood loss that should necessitate prompt referral among some of the CHWs. The Pathfinder International through its intervention 
namely clinical and community action to address postpartum hemorrhage (CCA-PPH) in Nigeria collaborated with the nursing and midwifery council of Nigeria (NMCN) to train midwives on identification, management and referral issues relating to PPH at the community level. ${ }^{17}$ From the findings of this study, it shows that the CHWs are knowledgeable that a woman who has lost up to $300 \mathrm{ml}$ of blood at the grassroots should be prepared for referral to next level of care as stipulated in the CCA-PPH training modules for nursemidwives. However, many of them still feel that the woman who lost $500 \mathrm{ml}$ of blood still need not be referred until she has lost up to $1000 \mathrm{ml}$ of blood. This finding may be related to the large number of CHEWs and $\mathrm{CHO}$ who have not received formal training in this regard. Somehow, some of the CHWs could not identify the danger signs of PPH. Rapid recognition and identification of risk factors for PPH plays a crucial role in its management of PPH. This further suggests that there should be continuous capacity building for CHWs at grassroots level in relation to recognition and prompt referral of $\mathrm{PPH}$ cases.

Findings from this study show that $51 \%$ of the CHWs had negative attitude towards prompt referral of women with PPH. This is in line with the result of study conducted by Nshimirimana et al, in Kenya that attitudes of healthcare workers towards referral is poor. ${ }^{18}$ This has a lot of implications for control of PPH. Notably, a delay in getting needed care is one of the most common reasons mothers die from hemorrhage. ${ }^{19}$ The importance of effective and timely referrals in an obstetric emergency is related to the unpredictability of pregnancy complications and their potential to progress rapidly to become severe and life threatening.

Three factors (lack of blood drapes, no ambulance and bad roads) were statistically linked with $\mathrm{CHWs}$ attitude towards referral. In diagnosing, controlling and managing $\mathrm{PPH}$, the accurate estimation of blood loss after birth is very vital. It is very likely that the estimation of blood loss can result in error due to lack of knowledge and skill to do so. ${ }^{20}$ Accurate estimation of blood loss is known to reducing the severity and frequency of $\mathrm{PPH} .^{20}$

Healthcare workers need to be involved in policy and advocacy activities with government and relevant stakeholders to address the transportation and road challenges between the rural areas and urban areas where secondary and tertiary facilities are mostly located.

The bad roads contribute to the delay in reaching the secondary or tertiary facilities for EmOC. However, CHWs could utilize simple tools such as cell phones or any other related technologies to assess health related information on actions that can be taken to save the life of the affected women pending the time that she will be taken to the next level of care. ${ }^{21}$ Such tools could also be used to help the other facilities prepare to receive the patient for immediate EmOC.
There is need for a general overhaul of facilities at the community-based level to effectively support prompt identification and referral of women in dare need of emergency obstetric care services. Provision for blood drapes to accurately estimate blood loss for critical decision making in respect of whether to transfer women to the next level of care should be looked into. Availability of ambulance is necessary at the grassroots level to ease the transfer of affected women for EmOC. Nurse midwives and other healthcare workers should be actively involved in community mobilization of women for early antenatal care. This will help to identify at risk women early and thus allow prompt referral of such women to next level of care for further management.

While this study gives information on the knowledge of CHWs and their attitude towards referral of women with postpartum hemorrhage, the geographical focus may limit the generalizability of these results. Findings from this study did not consider women who deliver outside community-based healthcare facilities where trained skilled attendants are not available and the public health importance of accurate measurement of blood loss may be different.

\section{CONCLUSION}

This study concluded that majority of community-based healthcare workers in the study settings have good knowledge of features, identification, prevention and referral of postpartum haemorrhage cases. Result also shows that majority have poor attitudes towards prompt referral of women affected with postpartum haemorrhage for emergency obstetric care.

\section{Funding: No funding sources}

Conflict of interest: None declared

Ethical approval: The study was approved by the Health

Research Ethics Committee (Number: IPH/OAU/12/650) of the Institute of Public Health, Obafemi Awolowo University, Ile-Ife

\section{REFERENCES}

1. World Health Organization. Trends in maternal mortality: 1990 to 2015: estimates by WHO, UNICEF, UNFPA, World Bank Group and the United Nations Population Division. Geneva: World Health Organization, 2015. Available at: http://www.afro.who.int/sites/default/files/201705/trends-in-maternal-mortality-1990-to-2015.pdf. Accessed 25 July 2017.

2. World Health Organization. WHO Recommendation for the prevention and treatment of Postpartum Haemorrhage. WHO Press, 2012. Available at: http://www.who.int/ins/bitscreen/10665/75411/1/978 9241548502_eng.pdf. Accessed 5 July 2016.

3. Tort J, Rozenberg P, Traoré M, Fournier P, Dumont A. Factors associated with postpartum haemorrhage maternal death in referral hospitals in Senegal and 
Mali: a cross-sectional epidemiological survey. BMC Preg Childbirth. 2015;15:235.

4. Smith JR. Postpartum haemorrhage. Medscape. Available at: https://emedicine.medscape. com/article/27503-overview. Accessed 13 December 2017.

5. World Health Organization. Reducing the global burden: Post-partum Haemorrhage. Making pregnancy safer; WHO 2007. Available at: http://www.who.int/maternal_child_adolescent/docu ments/newsletter/mps_newsletter_issue4.pdf. Accessed 7 July 2016.

6. Sentilhes L, Vayssiere C, Deneuy-Tharaux C, Sentilhes L, Vayssière C, Deneux-Tharaux C, et al. Postpartum hemorrhage: guidelines for clinical practice from the French College of Gynaecologists and Obstetricians (CNGOF): in collaboration with the French Society of Anesthesiology and Intensive Care (SFAR). Eu J Obstet Gynecol Repro Biol. 2016;198:12-2.

7. Bartlett L, Cantor D, Lynam P, Kaur G, Rawlins B, Ricca J, et al. Facility-based active management of the third stage of labour: assessment of quality in six countries in sub-Saharan Africa. Bullet World Health Organization. 2015;93:759-67.

8. Abodunrin OL, Akande TM, Osagbemi GK. Awareness and perception toward referral in health care: a study of adult residents in Ilorin, Nigeria. Anna African Med. 2010;9(3):176-80.

9. Singh AS, Masuku MB. Sampling techniques and determination of sample size in applied statistics research: an overview. Int $\mathrm{J}$ Econ Comm Manag. 2014;2(11);1-22.

10. Ebuehi OM, Chinda GN, Sotund, OM, Oyetoyan SA. Emergency obstetric care: urban versus rural comparison of health workers' knowledge, attitude and practice in river state, Nigeria- implications for maternal health care in Rivers State. Clin Med Diag. 2013;3(2):29-51.

11. Kilpatrick SJ, Prentice P, Jones RL, Geller S. Reducing maternal deaths through state maternal mortality review. J Women's Health. 2012;21(9):905-9.

12. Della TM, Kilpatrick SJ, Hibbard JU, Simonson L, Scott, Koch A, Geller SE. Assessing preventability for obstetric hemorrhage. Am J Perinatol. 2011;28(10):753-60.

13. National Primary Health Care Development Agency (NPHCDA). Minimum Standards for Primary Health Care in Nigeria. NPHCDA, 2015. Available at: http://www.nphcda.gov.ng/Reports\%20and\%20Publi cations/Minimum\%20Standards\%20for\%20Primary
$\% 20$ Health\%20Care $\% 20$ in $\% 20$ Nigeria.pdf.

Accessed 24 October 2016.

14. Darkwa EK, Newman MS, Kawkab M, Chowdhury ME. A qualitative study of factors influencing retention of doctors and nurses at rural healthcare facilities in Bangladesh. BMC Health Services Res. 2015; 15:344.

15. Faiza AN. Knowledge and practice of nursemidwives regarding management and prevention of postpartum haemorrhage in the selected teaching hospitals, Khartoum State-Sudan. Indian J Appl Res. 2014;5(4):634-8.

16. Jaber EA, Abbas, IM. Assessment of licensed indigenous midwives' knowledge concerning prevention and management of postpartum hemorrhage in Baghdad city. Iraqi Nat $\mathbf{J}$ Nurs Special. 2011;24(2):1-12.

17. Pathfinder International. Clinical and community action to address postpartum hemorrhage (CCCPPH) Tool Kit. Pathfinder 2006. Available at: https://www.k4health.org/sites/default/files/Clinicaland-Community-Action-to-Address-PostpartumHemorrhage-Table-of-Contents.pdf. Accessed 14 May 2018.

18. Nshimirimana DE, Mwaura-Tenambergen W, Kokonya D, Adoyo M. Attitudes of primary health care (PHC) gatekeepers towards patient referral policy, Machakos County, Kenya. Sci J Pub Health. 2016;14(4):284-8.

19. World Health Organization, 2003. Essential antenatal, perinatal and postpartum care training modules. WHO Regional Office for Europe, 2003. Available at: http://www.euro.who.int/_ data/assets/pdf_file/0013/131521/E79235.pdf. Accessed 31 October 2016.

20. Martins HE, de Souza MD, Khanum S, Naz N, Souza AC. The practice of nursing in the prevention and control of postpartum hemorrhage: an integrative review. Am J Nur. 2016;5(1):8-15.

21. Andreatta P, Debpuur D, Danquah A, Perosky J. Using cell phones to collect postpartum hemorrhage outcome data in rural Ghana. Int J Gynecol Obstet. 2011;113(2):148-51.

Cite this article as: Olowokere $\mathrm{AE}$, Olajubu AO, Ayeni IE, Aremu OO. Healthcare workers' knowledge and attitude towards prompt referral of women with postpartum haemorrhage in Nigeria: a community-based study. Int J Reprod Contracept Obstet Gynecol 2020;9:335-41. 